\title{
Intercellular Communication
}

\author{
Nuri Faruk Aykan \\ Istanbul University, Institute of Oncology, \\ Turkey
}

\section{Introduction}

Intercellular communication (transfert of information) is an essential issue for continuity of life in multicellular organisms. Several types of communication systems coordinate body functions to maintain homeostasis (Guyton \& Hall, 2000). Until now, it has been accepted that two major organ systems control all physiologic processes within the human body: The endocrine system and the nervous system (Greenspan \& Gardner, 2004). Beside them, a third organ system, immune system, is a super-system which provide recognition and destroy of foreign cells by specific coordination between their cells again within the body. The contact and communication between immun cells are used for the distinction between self and non-self. In recent years, considerable data supported the existence of dynamic interactions between these super-systems. For example, neuro-endocrine, neuro-immune, psycho-neuro-immuno-endocrinological cross communications have been identified (Downing \& Miyan, 2000; Sternberg, 1997; Weihe et al., 1991). In addition, within organ systems, autocrine, paracrine, juxtacrine, neurocrine, lumencrine (exocrine) and finally intracrine communications have been defined (di Sant'Agnese, 1992; Greenspan \& Gardner, 2004; Guyton \& Hall, 2000; Hansson \& Abrahamsson, 2001; Krantic et al., 2004; Miller, 2003; Patel et al., 1993; Re \& Bryan, 1984; Re, 1989; Ruan \& Lai, 2004; Sporn \& Todaro, 1980; Sporn \& Roberts, 1992; Zimmerman et al., 1993) (Figure 1). Intercellular communication in the organism is realized by specific molecules, except neural transmission exerted by action potentials (Despopoulos \& Silbernagl, 2003; Faller \& Schuenke, 2004; Guyton \& Hall, 2000) and except information transfer by biophoton emission which has been reported very recently (Albrecht-Buehler, 1992; Cohen \& Popp, 1997; Fels, 2009; Jaffe, 2005; Musumeci et al., 1999; Niggli, 1992). This review especially addresses chemical communication systems in the human body by simplified examples.

\section{Modes of communication}

This chapter will attempt to summarize the modes of communications in this order below; autocrine (including intracrine), paracrine (including juxtacrine, gap junctional, via Tunneling Nano-Tube like structures), endocrine, neurocrine (including neuro-endocrine) and lumencrine communications.

\subsection{Autocrine communication}

Autocrine communication (derived from auto: self and krinein: to secrete, Greek) is an activity of a hormone or growth factors (GFs) that binds to and affects the same cell that 
secreted it. These substances directly stimulate (or inhibit) the cell via their surface receptors. Autocrine secretion was described first by Sporn and Todaro in 1980. It explains self-regulation of cells. This concept is now not only important to explain malignant transformation, but is also mainstay of embryogenesis and morphogenesis. Autocrine regulation provides selective growth advantages during the earliest stages of embryogenesis before the development of a functioning circulatory system and endocrine function (Dockray, 1979; Sporn \& Todaro 1980).

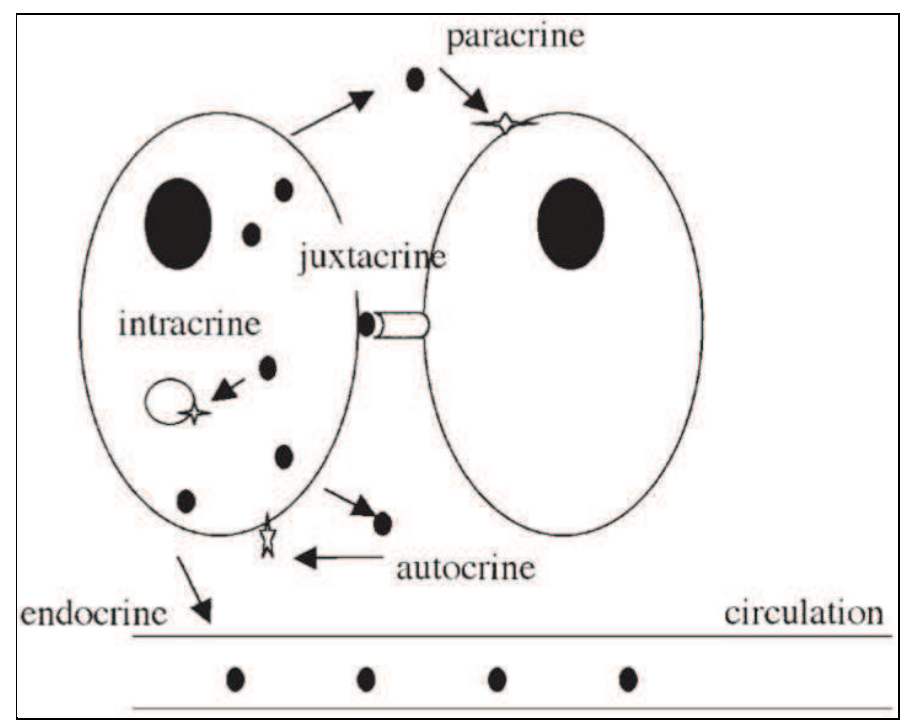

Fig. 1. Several intercellular modes of communication (courtesy of Mao-De Lai, corresponding author of the article Ruan \& Lai, 2004)

Autocrine secretion is an important phenomenon in the regulation of the behavior of many normal cells such as macrophages, lymphocytes, fibroblasts and vascular smooth muscle cells. This regulation can be positive or negative manner. For example, oncogenes such as EGF, TGF- $\alpha$ and PDGF enhance autocrine pathways to increase cell replication during carcinogenesis. Same peptides also have an important autocrine role in tissue repair and wound healing in normal physiology. On the other hand TGF- $\beta$ is a significant negative autocrine regulator in the adenoma-carcinoma sequence of human colon carcinogenesis (Sporn \& Roberts, 1992). But, TGF- $\beta$ is bifuntional like many other peptide growth factors and its stimulatory or inhibitory effects depends on many factors including cell type specificity, cell growth condition, and some other factors (Sporn \& Roberts, 1988; Ruan \& Lai 2004). In fact, cells are different than simple mechanical devices, they take new information from its environment and depending on conditions they give an appropriate response (Sporn \& Roberts, 1992). For example, a specific autocrine cytokine such as TGF- $\beta$ or interleukin- 6 can act either positive or negative signal for growth in a given cell (Sporn \& Roberts, 1988; Akira et al., 1990). Autocrine communication can be considered as a primitive mechanism of humoral regulation than endocrine secretion (Sporn \& Todaro, 1980). 


\subsubsection{Internal autocrine (intracrine) communication}

Another type of autocrine regulation is realized inside the cell. Internal autocrine or intracrine mode of action which is described first Re RN et al in 1984, indicates that some peptide hormones and growth factors (intracrines) bind and act in the cellular interior either after internalization by target cells or retention in their cells of synthesis $(\operatorname{Re} \&$ Bryan, 1984; Re, 1989). Some endogenous cytokines such as interleukin-3 or PDGF can be modified and retained within the cell to ensure internal cellular action and they have high degree of intracellular biologic activity (Bejcek et al, 1989; Dunbar et al, 1989; Keating \& Williams 1988). As shown in Figure 1, a chemical mediator (peptide growth factor or hormone) interacts with its specific receptor within the cell, bypassing the need of secretion outside, to exert functional activity. An intracrine system, in contrast to endocrine system, requires minimal amounts of biologically active hormones to exert their maximum hormonal effects. For this reason, the intracrine system plays an important role especially in the development of hormone-dependent neoplasms such as breast, prostate malignancies. As another example, locally produced bioactive androgens and/or estrogens exert their action in the cells where synthesis occurs without release in the extracellular space including circulation (Sasano et al., 2008). Labrie and colleagues described the formation of active androgens (such as DHT) from the inactive adrenal precursors in the some tissues or cells in adenocarcinoma of the prostate where biosynthesis takes place without release into the extracellular space as "intracrine activity" (Labrie et al., 1995, 2003, Sasano et al., 2008). On the other hand, estrogendependent breast carcinoma in which aromatase converts circulating androgens to estrogens (from androstenedione to estrone and from testosterone to estradiol, respectively) should also be considered as "intracrine tissue". One of the most studied example of intracrine function is about local renin-angiotensin system (RAS). As it is known, the proteolytic enzyme renin (an aspartyl protease) which cleaves angiotensinogen, is secreted mostly from juxtaglomerular cells in the renal afferent arteriole. Reduced renal arteriolar blood pressure and then the activation of local $\beta 2$ adrenoreceptor stimulates the secretion of renin. The major source of plasma angiotensinogen is the liver, but it is also formed for local use in the heart and the brain. Cleavage of angiotensinogen by renin yields angiotensin I which has no biological activity. Further, angiotensin II is produced from angiotensin I by endothelial angiotensin-converting enzyme (ACE) and angiotensin III is produced from angiotensin II by aminopeptidase. Angiotensin II is a potent constrictor of vascular smooth muscle, and this action is mediated by the $\mathrm{AT}_{1}$ receptor. Angiotensin II and III act on zona glomerulosa cells in the adrenal cortex and promote secretion of aldosterone. Today we know that renin is not simply a circulating enzyme but is a hormone and it is also an intracrine. Renin and angiotensin are also active within cells. A complete intracrine RAS exists in some cells (Re \& Bryan, 1984). For example, an adrenal intracellular RAS has been reported (Peters et al., 1999). Prorenin and renin can bind to specific cellular receptors. Prorenin, and to a lesser extent, renin, can be internalized by cells where angiotensin II is produced (Re, 2003a). Internalized, activated prorenin causes both hypertension and cardiac injury. Nuclear angiotensin receptors were also reported (Re, 1999). There is a renin transcript in some cells (adrenal, brain) lacking the sequence encoding the secretory signal piece (renin exon 1A) (Clausmeyer et al., 2000; Peters et al., 
1999). Renin exon 1A generates angiotensin in mitochondria which have angiotensin receptors and stimulates aldosterone secretion in the adrenal cortex. This aldosterone secretion is inhibited by the angiotensin receptor blocker losartan (Peters et al., 1999). Renin exon $1 \mathrm{~A}$ is upregulated by nephrectomy. Adrenal mitochondrial renin granules increase following nephrectomy (Peters et al, 1999). Release of angiotensin II in the intracellular space upregulates a series of genes including PDGF which stimulated proliferation (Re, 2003b). It has been reported that renin exon $1 \mathrm{~A}$ upregulated in the ventricles of rats after myocardial infarction. Intracrine RAS may have a reasonable role in the processes like left ventricular hypertrophy, cardiac fibrosis and some forms of arrhytmia (Re, 2003b). So, the existence of intracrine RAS can be clinically important. Another important area related to intracrinology is the angiogenesis. Many intracrines (angiogenin, FGF-2, angiotensin) are angiogenic either directly or through the stimulation of vascular endothelial growth factor (VEGF) (Li \& Keller, 2000; Re, 1999). Angiogenin is an RNase and needs nucleolar translocation to stimulate angiogenesis. VEGF also is an intracrine. Lee and colleagues, demonstrated that VEGFR1 expression was abundant in breast cancer cells (Lee et al., 2007). It was predominantly expressed internally in MDAMB-231 and MCF-7 breast cancer cells and VEGFR1 antibody had no effects on the survival of these cells. Learning this intracrine concept has a practical significance because the usage of therapeutic antibodies against GFs have serious limitations in that an internal autocrine loop can not be accessible to antibody therapy (Sporn \& Roberts, 1992).

\subsection{Paracrine communication}

Paracrine communication (derived from para: from beside by, Greek) is an activity of an agent (hormone or growth factor) that binds to and affects neighboring cells. The agent is directly released into the intercellular space and may involve many nearby cells that have receptors for this agent (Öberg, 1998; Raybould et al., 2003). One nice example of paracrine communication is the interaction between vascular endothelial cells and pericytes. The control of proliferation and migration of vascular endothelial cells can be mediated by neighboring cells; pericytes in a capillary (Antonelli-Orlidge et al, 1989), or smooth-muscle cells (Dennis \& Rifkin, 1991) in an artery. A capillary endothelial cell synthesize latent TGF- $\beta$ and a pericyte is required for activation of this latent molecule. This is a cooperative interaction via paracrine way. Loss of paracrine activation by pericytes may contribute diabetic proliferative vascular retinopathy (Antonelli-Orlidge et al, 1989). During recent years, interactions between endothelial cells and mural cells (pericytes and vascular smooth muscle cells) have gained increasing attention in physiological and pathological conditions including tumor angiogenesis, diabetic retinopathy, hereditary telangiectasia, lymphedema and hereditary stroke and dementia syndrome (Armulik et al, 2005). Some signaling pathways such as angiopoietin-Tie2, PDGF-B/PDGFR- $\beta$ are described between endothelial cells and pericytes. Nitric oxide (NO) is also a paracrine agent; endothelial cells produce NO (and citrulline) from arginine as a substrate by endothelial nitric oxide synthase, and it diffuses into smooth muscle where induces relaxation and dilatation of blood vessels (Schechter \& Gladwin, 2003). As another example, paracrine interactions between immune cells and fibroblasts are required for the normal repair of injured tissue (Sporn \& Roberts, 1992). On the other hand, it has been demonstrated recently the multicellular autocrine and paracrine cross 
talk in the inflammatory tumor microenvironment; for example RAGE (receptor for advanced glycation end products) engagement in cancer cell surface with its ligands (AGEs, S100/calgranulins, amyloid A, amyloid- $\beta$ and DNA-binding protein HMGB1) which are expressed and secreted by many cell types within the tumor microenvironment including fibroblasts, leukocytes and vascular cells, produces activation of multiple intracellular signalling mechanisms involved in several inflammation-associated clinical entities, such as cancer, diabetes, renal and heart failures and neurodegenerative diseases (Rojas et al, 2010). Intercellular bidirectional paracrine communication is essential also either in spermatogenesis or development of an egg competent to undergo fertilization and embryogenesis (Matzuk et al, 2002).

\subsubsection{Juxtacrine communication}

Another kind of paracrine communication between signaling and target cells is juxtacrine interactions. Juxtacrine mode of action (derived from juxta: nearby, Latin) is a direct and intimate contact between two cells such as macrophage-T lymphocyte, spermatogoniaSertoli cell or endothelial cell (EC) and the leukocyte (Krantic et al., 2004; Patel et al., 1993; Zimmerman et al., 1993). This signaling form provides a mechanism for strict spatial control of activation of one cell by another and juxtacrine signaling is likely to be common in physiologic events that require tight regulation (Zimmerman et al., 1993). The term "juxtacrine" was coined by Anklesaria and Massagué and colleagues in 1990 (Anklesaria et al, 1990; Massagué, 1990). In juxtacrine systems the signaling factor acts while associated with the surface of signaling cells, rather than acting in the fluid phase. In the example of spermatogonia-Sertoli cell, spermatogonia produce somatostatin and Sertoli cells express sst2 receptors. Activation of sst2 receptor by somatostatin binding leads to a diminished expression of stem cell factor (SCF) expression by Sertoli cells. This inhibition of SCF is associated with a decrease in spermatogonia proliferation (Krantic et al, 2004). Immunologic synapse which involve multiple adhesion and regulatory molecules between antigenpresenting cell (APC) and T-cell can also be considered juxtacrine communication (Bromley et al. 2001; Biggs et al, 2011). Juxtacrine secretion provides a unique mechanism for preventing an undesirable diffuse action of a given cytokine on innocent bystander cells (Sporn and Roberts, 1992). For example tumor necrosis factor (TNF) is a cytokine that can act by a juxtacrine mechanism has been implicated as a critical mediator of cachexia, septic shock, rheumatoid artritis, autoimmune states, induction of HIV expression and the killing of tumor cells. Transmembrane form of TNF is highly active and cell-to-cell contact, without secretion into the intercellular space, is sufficient for TNF to kill a target tumor cell (Perez et al., 1990). Disruption of juxtacrine signaling may lead to pathologic outcomes, oxidantinjured endothelial cells is one example and this disruption may be a fundamental process in adult respiratory distress syndrome, shock and similar tissue injuries (Zimmerman et al., 1993).

\subsubsection{Gap Junctional Intercellular Communication (GJIC)}

GJIC is different than the other modes of communication where a ligand and its receptor interaction exists by diffuse (autocrine, paracrine, endocrine) or non-diffuse (juxtacrine) mechanism. This type of communication between adjacent cells is mediated via 
intercellular channels that cluster in specialized regions of the plasma membrane to form gap junctions (Robertson 1963, Revel and Karnovsky 1967, Wei et al 2004, as cited in Meşe et al, 2006). Gap junctional channels link the cytoplasm of two cells, and provide the exchange of ions $\left(\mathrm{K}+, \mathrm{Ca}^{2}+\right)$, second messengers (cAMP, cGMP, IP3) and small metabolites like glucose (Kanno \& Loewenstein, 1964; Lawrence et al., 1978, as cited in Meşe et al., 2006) . Valiunas et al (2005), recently showed that transfer of small interfering RNAs between neighboring cells trough gap junctions. GJIC is essential for many pysiological events such as cell synchronization, differentiation, cell growth, and metabolic coordination of avascular organs including epidermis and lens (Vinken et al., 2006; White and Paul, 1999). GJIC forms a close electrical and metabolic unit (syncytium). It is present in the epithelium, many smooth muscles, the myocardium, and the glia of the central nervous system (Despopoulos \& Silbernagl, 2003). Electric coupling permits the transfer of excitation (electrical synapses); many examples can be given for this wave of excitation in the body such as atrium and ventricles of the heart, stomach, intestine, biliary tract, uterus and ureter. Gap junctions are formed by two unrelated protein families, the pannexins and connexins (Meşe et al, 2006). Connexins have four transmembrane domains and six connexins oligomerize to form hemichannels called "connexons". One connexon docks with another connexon on the adjacent cell, thereby forming a common channel which substances with molecular masses of up to around 1 $\mathrm{kDa}$ can pass (Despopoulos \& Silbernagl, 2003). This organization requires the membranes of two adjacent cells leaving a 2-4 nm gap (Bruzzone et al., 1996; White \& Paul 1999). Gap junction channels are selective permeable. There are at least 21 connexin isoforms and connexons can be formed either from a single type of connexin or from more than one type, leading to the formation of either homomeric or heteromeric hemichannels, respectively (Meşe et al, 2006) and this characteristic can explain selective permeability. For example connexin32 homomeric hemichannels were permeable to both cAMP and cGMP whereas connexin26/connexin32 hemichannels were permeable mainly to cGMP. The "Contact inhibition" process can be mediated in some cells by gap junctions (Trosko, 2007).

\subsubsection{Intercellular communication via Tunneling Nano-Tube (TNT) like structures}

Very recently, a novel mechanism for intercellular communication was discovered by which nanotubular structures, consisting of thin membrane bridges, mediate membrane continuity between mammalian cells (Rustom et al., 2004). These channels, referred to as tunneling nanotubes (TNT), were shown to actively traffic cytosolic content from cell to cell within the interior of their filaments (Rustom et al., 2004). TNTs were first described in cultured rat pheochromocytoma PC12 cells. Calcium ions, MHC class I proteins, prions, viral and bacterial pathogens, small organelles of the endosomal/lysosomal system and mitochondria are among identified TNT cargos until now (Eugenin et al., 2009; Gerdes, 2009; Gerdes et al., 2007; Gurke et al., 2008; Koyanagi et al., 2005). Intercellular exchange via TNT based cell-communication was reported in cells which have high motility and plasticity like progenitor cells, immune cells and tumor cells. The exchange of endosomerelated organelles and other cellular components over long distances and the coordination of signaling between the connected cells are realized by this way (Rustom et al. 2004, Gerdes et al. 2007; Gerdes \& Carvalho, 2008). Domhan et al (2011) reported also 
intercellular exchange by TNT, between human renal proximal epithelial cells; this may play an important role in renal physiology.

\subsection{Endocrine communication}

Endocrine system (derived from endon: inside, krinein: to secrete, Greek) is a radio-like communication system. It consists of endocrine glands and specialized groups of cells within organs of multicellular organism. The endocrine glands sends its hormonal messages like a radio broadcast to essentially all cells of human body by secretion into the circulation of blood. Hormones are chemical messengers of endocrine communication. They are transported through the bloodstream and cells which have a receiver (a receptor) take this message (Greenspan \& Gardner, 2004). Hormones can be proteins (eg growth hormone, FSH, LH), peptides or peptide derivatives (eg ACTH), amino acid derivatives (eg catecholamines, thyroid hormones). Steroid hormones and vitamin D are derived from cholesterol. Retinoids are derived from carotenoids and eicosanoids are derived from fatty acids. Some hormones (eg insulin, growth hormone, prolactin, catecholamines) bind cell surface receptors, others (steroids, thyroid hormones) bind to intracellular receptors that act in the nucleus. Hormone binding alters receptor conformation and this alteration transmits the binding information into postreceptor events that influence cellular function (Greenspan \& Gardner, 2004). Hormones serve as messenger substances that are mainly utilized for slower, long-term transmission of signals; they are carried by the blood to target structures great distances away (Despopoulos \& Silbernagl, 2003). Endocrine system is essentially responsible for control and integration of multicellular organism. The principal functions of endocrine hormones at the target level, are to control and regulate enzyme activity, transport processes, growth, secretion of other hormones, exert negative or positive feedback control and coordinate cells of same type. Endocrinology is a great and expanding discipline of science (Table 1).

\subsection{Neurocrine communication}

Nervous communication is point-to-point through nerves and electrical in nature and fast. By this aspect, communication by nervous system is similar to sending messages by conventional telephone so it is a cable phone-like system. In neurocrine communication, neuronal cells release their products directly into the synaptic space; they act on another cell type (Öberg, 1998). A synapse is the site where the axon of a neuron communicates with effectors or other neurons (Despopoulos \& Silbernagl, 2003). According to the termination of an axon, the synapse may be axo-dendritic, axo-axonic or axo-somatic (Faller and Schuenke, 2004). Chemical synapses utilize (neuro)transmitters for the transmission of information. The arrival of action potential to the synapse in the axon triggers the release of transmitter from the presynaptic terminals. The transmitter then diffuses across the narrow intercellular gap (synaptic cleft) which is approximately $10-50 \mathrm{~nm}$, and it binds postsynaptic receptors in the membrane of a neuron or a glandular or muscle cell (Despopoulos \& Silbernagl, 2003; Faller \& Schuenke, 2004). Transmitters are released by exocytosis of synaptic cytosolic storage vesicles. Depending on the type of transmitter and receptor involved, the effect on the postsynaptic membrane may be excitatory or inhibitory. Neuroscience, like endocrinology is also another essential interdisciplinary science (Table 1). 


\subsubsection{Neuro-endocrine communication}

In this system, neurocrine and endocrine communications exist together. Neuroendocrinology is a studying science the interactions between nervous and endocrine systems (Greenspan \& Gardner, 2004). There are two major mechanism of neural regulation of endocrine function; the first is neurosecretion which refers to neurons that secrete hormones into the circulation. For example, hypothalamic neurons synthesize and secrete hormones (releasing or release inhibiting hormones) into blood vessels (a kind of portal venous system) that communicate with the anterior pituitary. Posterior pituitary hormones (oxytocin and $\mathrm{ADH}$ ) are transported from hypothalamic neurons to the ends of the axons in the neurohypophysis where enter the systemic circulation directly (Despopoulos \& Silbernagl, 2003). The second is the direct autonomic innervation of endocrine tissues (such as adrenal medulla, pancreatic islets and gut) which couples central nervous system signals to hormone release. Enterochromaffin cells (EC) in the gastrointestinal tract have close contact with nerve elements of both afferent and efferent type adjacent to the basal lamina of the mucosa and true synapses have been identified (Ahlman \& Dahlström, 1983). One of the interesting example of neuro-endocrine communication is the stimulation of gastric secretion in the cephalic phase (Guyton \& Hall, 2000). In this phase of gastric secretion, when we see or smell a nice food while we are hungry, gastric secretion increases even before food enters the stomach (Pavlov's sham-feeding assay). Neurogenic signals come by vagus to stomach. In this point the first chemical messengers are acetylcholine and gastrin-releasing peptide (GRP). It has been demonstrated that $G$ cells have muscarinic receptors and muscarine-like action, particularly in the M3 receptor-mediated route, plays a significant role in acetylcholinemediated gastrin secretion (Matsuno et al., 1997). And we know also that cephalic phase of acid secretion is augmented predominantly by acetylcholine and gastrin while histamine is of major importance during the gastric phase (Schusdziarra, 1993). Martinez and colleagues demonstrated similarly that atropine and gastrin antibody decrease basal acid secretion while gastrin antibody only did not block the rise in acid during sham feeding (Martinez et al., 2002). Gastrin stimulated acid secretion is through releasing histamine from ECL (enterochromaffine-like) cells (Waldum et al., 2002). Cholecystokinin 2 (gastrin) receptors in the stomach are only in the ECL cells (Waldum et al., 2002). Then, ECL cells release histamine and stimulate oxinthic cells via paracrine way (by binding $\mathrm{H}_{2}$ receptors) to produce $\mathrm{HCl}$. As a control of gastric acid secretion, somatostatin (SS14) secreted by D cells inhibits both $\mathrm{G}$ cell and the parietal cell.

\subsection{Lumencrine (exocrine) communication}

Another type of communication is lumencrine (exocrine) secretion in the open cell types like pancreas and prostate. Like the other modes of regulations, lumencrine mechanism can also play an important regulatory role both during growth and differentiation of the prostate as well as in the secretory process of the mature gland (di Sant'Agnese, 1992). Calcitonin, GRP (bombesin) and somatostatin have been reported in semen that they may be directly secreted into the ejaculate (Arver \& Sjoberg, 1982; Bucht et al, 1986; Gnessi et al, 1989; Sasaki \& Yoshinaga, 1989; Sjoberg et al, 1980; cited in di Sant'Agnese, 1992). It has also been shown that a decrease in seminal ionized calcium correlates with a decrease in motility of sperm 
(Prien et al., 1990). On the other hand, lumencrine secretion of pancreatic enzymes, water and ions play a major role in the duodenal phase of the digestion (Raybould et al., 2003) (Figure 2).

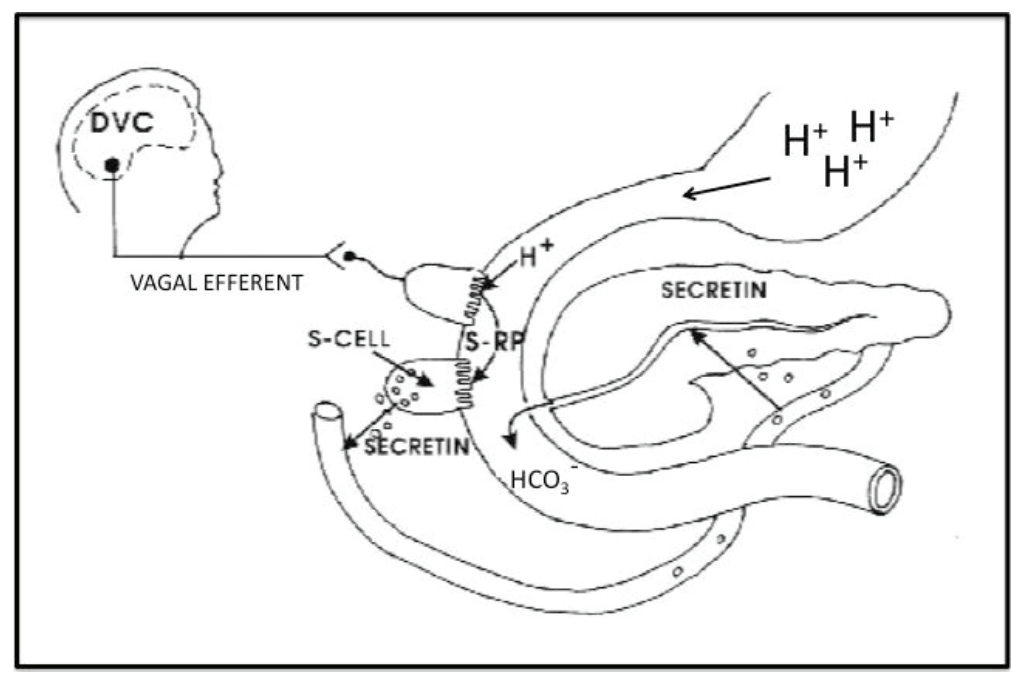

Fig. 2. Lumencrine, endocrine and neuro-endocrine communications during the regulation of $\mathrm{pH}$ in duodenum (modified from Li et al., and cited in Konturek et al, 2003). DVC: Dorsal vagal center, S-RP: Secretin releasing peptide.

\subsection{Hypotheses about intercellular communication}

Information theory was developed by Shannon, approximately more than 60 years ago (Shannon, 1948), to determine quantitative aspects of information exchange between a biologic source and a biologic receiver (Mayer and Baldi, 1991). According to this theory, peptidergic cell-to-cell communication between neurocrine, endocrine and growth factormediated messages require different encoding and decoding strategies. On the other hand qualitative component of the exchanged message is concerned with semantic information such as human language. The word "information" means "knowledge of order" in common language (Vincent, 1994). The laws of linguistics and semantics are valid not only at the organismic level, but also at the cellular and molecular level (Vincent, 1994). Today, we know that bacteria communicate by quorum sensing molecules (Miller \& Bassler, 2001). Microbian language contains two component system which consists of a signal (input) and a response (output) (Pechère, 2007). Sensors receive the signal, effectors make the response. Cells use a molecule-based language called cellese which has the counterparts of sound- and visual-based human language (humanese) (Ji, 1999). What is transmitted is the meaning of the message (significance) which can be memorized by the cell, providing a possible following use (Vincent, 1994). It was suggested that cytokines can be viewed as symbols in an intracellular language (Sporn \& Roberts, 1988). The participation of the extracellular matrix in the language of intercellular communication is a way that multicellular organisms can use past experience to determine the response to 
cytokines and interactions with matrix enable cytokines to elicit adaptive responses (Nathan \& Sporn, 1991). Unique phenotype of cells based their carbohydrate determinants on their cell surfaces is another area of interest (glycobiology) in intercellular communication (Sporn \& Roberts, 1992). Many peptide growth factors and cytokines are described and they are multifunctional ((Sporn \& Roberts, 1988). It is apparent that they form part of complex cellular signaling language, in which the individual peptides are the equivalent of characters of an alphabet or code (Sporn \& Roberts, 1988). Five years ago, we proposed an intercellular network model (message-adjusted network) in the physiology of gastro-entero-pancreatic (GEP) endocrine system, based on up-to-date information from medical publications (Aykan, 2007). In this network; message is an input which can affect the physiologic equilibrium, mission is an output to improve the disequilibrium, aim is always maintenance of homeostasis. Messages are picked up by biologic sensors or detectors. If we orientate to a transmission of a unique, physiologic, simple message we can design its proper network (Figure 3). In this model, different cells use different chemical messengers via different modes of regulations to transmit the same message. These message-adjusted intercellular networks may be most important (or unique) determinants in the formation of proper, environmentally adaptive multi-cellular organizations in the biology and it should be tested in the laboratory.

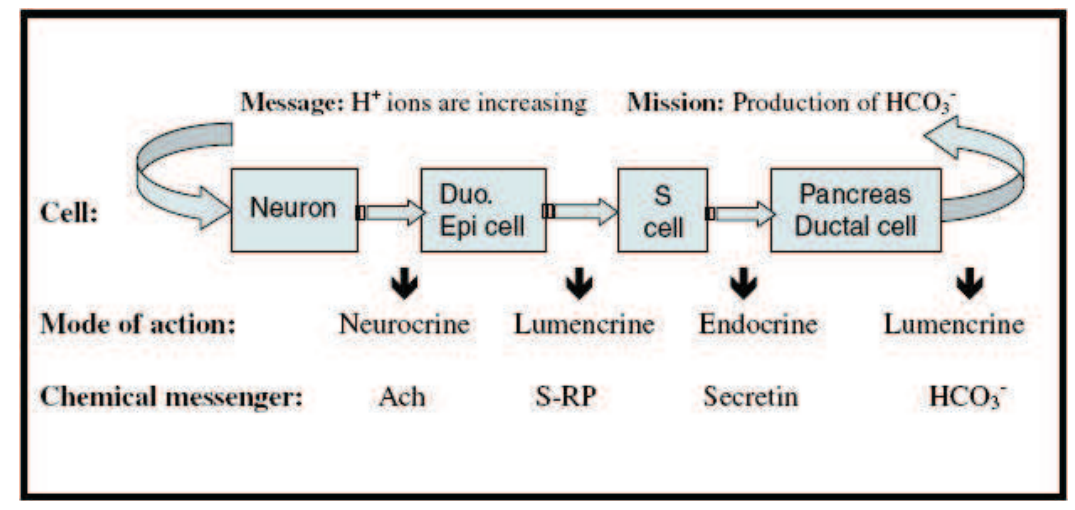

Fig. 3. A message-adjusted network model in the regulation of $\mathrm{pH}$ at the duodenum.

Unbuffered hydrogen ions coming from stomach stimulate secretin release from $S$ cells in the duodenum. Major effect of secretin is the secretion of bicarbonate ions from pancreatic ductal epithelium. Vagal stimulation results also small stimulation of pancreatic bicarbonate secretion.

Human body has more than 200 different cells (Alberts et al., 1994). The crucial question in the field of communication physiology is that "how they communicate each one with another?" Today, we know the words that are chemical messengers (bioactive peptides like hormones and neuromediators, cytokines, growth factors, some ions and other molecules), but we don't know languages specific to cell populations (tissue specific languages!). Although there is an expanding knowledge in molecular biology, some scientific disciplines which should be related to modes of communication are not developped yet in the literature (Table 1). 


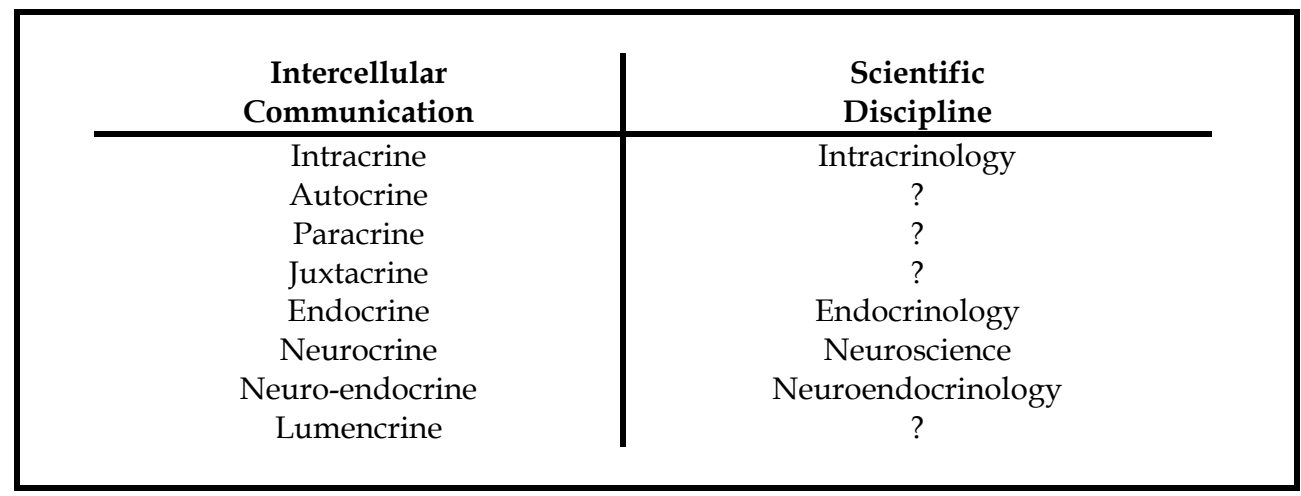

Table 1. Modes of intercellular communication and related scientific disciplines.

On the other hand, we suggest that pheromones can play a role in lumencrine interindividual unconscious communication (Mayer \& Baldi, 1991; Brennan \& Keverne, 2004; Knecht et al., 2003) but we don't know if there is a wireless-like intercellular communication. This type of communication, if there is, should be between mobile cells, such as circulating cells, spermatozoa or mature oocyte and it should be bi-directional to provide cell to cell crosstalk. One potential example can be the induction of hypertrophy of draining lymph nodes by mast-cell derived tumour necrosis factor during infection (Mc Lachlan et al., 2003). The mode of this action of mast cells is defined as a remote control mechanism (Buckland, 2003). A second candidate for wireless communication can be again in the immune system; substance $\mathrm{P}$ and its receptors have been detected in granulocytes, monocytes and lymphocytes (Ferone et al, 2001). A third and most interesting example may be in the spermatozoa-egg communication; recent studies indicate that olfactory receptors might be a role in the chemotaxis of spermatozoa (Sliwa, 2003; Spehr et al, 2004; Fukuda et al, 2004; Eisenbach \& Tur-Kaspa, 1999).

\section{Conclusion}

After human genome project (HU-GO) and protein organisations (HU-PO), it is time to resolve all parts of intercellular communication. Clarifying intercellular communication systems is as important as intracellular signal mechanisms. Finally, we believe that intercellular communication in our world becomes by specific molecules; these molecules are the words of the cell language.

\section{Acknowledgment}

Author thanks Ass. Prof. Barbaros Durgun, M.D. for his kind support in the preparation of figure 3 and Mao De Lai for kind permission of figure 1.

\section{References}

Ahlman, H. and Dahlström, A. (1983). Vagal mechanisms controlling serotonin release from the gastrointestinal tract and pyloric motor function. J Auton Nerv Syst 9:119-140. 
Akira, S., Hirano, T., Taga, T., \& Kishimoto, T. (1990). Biology of multifunctional cytokines: IL-6 and related molecules (IL-1 and TNF). FASEB J. 4:2860-2867.

Alberts B et al. (1994). Molecular biology of the cell. (3rd ed). Garland, p.1188.

Albrecht-Buehler, G. (1992). Rudimentary form of cellular "vision". Proc. Natl. Acad. Sci. USA, 89:8288-8292.

Anklesaria, P., J. Teixidó, M. Laiho, J. H. Pierce, J. S. Greenberger, \& J. Massagué. (1990). Cell-cell adhesion mediated by binding of membrane-anchored transforming growth factor $a$ to epidermal growth factor receptors promotes cell proliferation. Proc. Natl. Acad. Sci. USA 87:3289-3293.

Antonelli-Orlidge, A., Saunders, K.B., Smith, S.R. \& D'Amore, P.A. (1989). An activated form of transforming growth factor $\beta$ is produced by cocultures of endothelial cells and pericytes. Proc. Natl. Acad. Sci. USA. 86:4544-4548.

Armulik, A., Abramsson, A. \& Betsholtz, C. (2005). Endothelial/pericyte interactions. Circ Res. 97:512-523.

Aykan, N.F. (2007). Message-adjusted network (MAN) hypothesis in gastro-enteropancreatic (GEP) endocrine system. Medical Hypotheses, 69, 571-574.

Bejcek, B.E., Li, D.Y. \& Deuel, T.F. (1989). Transformation by v-sis occurs by an internal autoactivation mechanism. Science, 245:1496-1498.

Biggs, M.J.P., Milone, M.C., Santos, L.C., Gondarenko, A. \& Wind, S.J. (2011). Highresolution imaging of the immunological synapse and T-cell receptor microclustering through micrfabricated substrates. J. R. Soc. Interface. 8, 1462-1471.

Brennan, P.A., Keverne, E.B., (2004). Something in the air? New insights into mammalian pheromones. Curr Biol. 14(2):R81-9.

Bromley, S.K., Burack, W.R., Johnson, K.G., et al., (2001). The immunological synapse. Annu. Rev. Immunol. 19, 375-396.

Bruzzone, R., White, T.W., Paul, D.L. (1996) Connections with connexins: the molecular basis of direct intercellular signaling. Eur J Biochem 238:1-27.

Buckland, J. (2003). Mast cells act by remote control. Nature Rev. Immunol. 3, 927.

Clausmeyer, S., Reinecke A, Farrenkopf R, Unger T \& Peters J. (2000). Tissue-specific expression of a rat renin transcript lacking the coding sequence for the prefragment and its stimulation by myocardial infarction. Endocrinology 141: 2963-2970.

Cohen S and Popp FA, (1997). Low-level luminescence of the human skin. Skin Research and Technology 3: 177-180.

Dennis, P.A. and Rifkin, D.B. (1991). Cellular activation of latent transforming growth factor $\beta$ requires binding to the cation-independent mannose 6-phosphate/insulin-like growth factor type II receptor. Proc Natl Acad Sci USA. 88:580-584.

Despopoulos, A, Silbernagl, S. (Eds), (2003). Color Atlas of Physiology, 5th Edition, Georg Thieme Verlag, Stuttgart, New York.

di Sant'Agnese, P.A., (1992). Neuroendocrine differentiation in human prostatic carcinoma. Hum. Pathol. 23, 287-296.

Dockray, GJ. (1979). Evolutionary relationships of the gut hormones. Fed Proc. 38:2295-2301.

Domhan, S., Ma, L., Tai, A., Anaya, Z., Beheshti, A., Zeier, M., Hlatky, L. and Abdollahi, A. (2011). Intercellular communication by exchange of cytoplasmic material via tunneling nano-tube like structures in primary human renal epithelial cells. PLoS One 6(6): e21283. 
Downing, J.E., Miyan, J.A., (2000). Neural immunoregulation: Emerging roles for nerves in immune homeostasis and disease. Immunol. Today 21, 281-289.

Dunbar, C.E., Browder, T.M., Abrams, J.S. \& Nienhuis, A.W. (1989). COOH-terminalmodified interleukin-3 is retained intracellularly and stimulates autocrine growth. Science, 245:1493-1496.

Eisenbach, M. and Tur-Kaspa, I., (1999). Do human eggs attract spermatozoa? Bioessays. 21(3):203-210.

Eugenin, E.A., Gaskill, P.J., Berman, J.W. (2009) Tunneling nanotubes (TNT) are induced by HIV-infection of macrophages: a potential mechanism for intercellular HIV trafficking. Cell Immunol 254: 142-148.

Faller, A, Schuenke, M., (eds), (2004). The Human Body. An introduction to structure and function. Georg Thieme Verlag, Stuttgart, New York.

Fels, D. 2009. Cellular communication through light. PloS One, 4(4):e5086.

Ferone, D., Hofland, L.J., Colao, A. et al. (2001). Neuroendocrine aspects of immunolymphoproliferative diseases. Ann. Oncol. 12(Suppl. 2):S125-S130.

Fukuda, N., Yomogida, K., Okabe, M., Touhara, K. (2004). Functional characterization of a mouse testicular olfactory receptor and its role in chemosensing and in regulation of sperm motility. J. Cell Sci. 117(24):5835-45.

Gerdes, H.H. (2009) Prions tunnel between cells. Nat Cell Biol 11: 235-236.

Gerdes, H.H., Bukoreshtliev, N.V., Barroso, J.F. (2007) Tunneling nanotubes: a new route for the exchange of components between animal cells. FEBS Lett 581: 2194-2201.

Gerdes, H.H., Carvalho, R.N. (2008) Intercellular transfer mediated by tunneling nanotubes. Curr Opin Cell Biol 20: 470-475.

Greenspan, F.S., Gardner, D.G. (Eds), (2004). Basic and Clinical Endocrinology, Seventh Edition, pp. 2, McGraw-Hill, New York.

Gurke, S., Barroso, J.F., Hodneland, E., Bukoreshtliev, N.V., Schlicker, O., et al. (2008) Tunneling nanotube (TNT)-like structures facilitate a constitutive, actomyosin dependent exchange of endocytic organelles between normal rat kidney cells. Exp Cell Res 314: 3669-3683.

Guyton, A.C. and Hall, J.E. (Eds), (2000). Textbook of Medical Physiology, Tenth Edition, pp. 836, Saunders, Philadelphia.

Hansson, J., Abrahamsson, P.A., 2001. Neuroendocrine pathogenesis in adenocarcinoma of the prostate. Ann. Oncol. 12 (Suppl. 2): S145-S152.

Jaffe, L.F. (2005). Marine plants may polarize remote Fucus eggs via luminescence. Luminescence 20: 414-418.

Ji, S. (1999). The linguistics of DNA: words, sentences, grammar, phonetics, and semantics. Ann NY Acad Sci 870: 411-417.

Keating, M.T. \& Williams, L.T. (1988). Autocrine stimulation of intracellular PDGF receptors in v-sis-transformed cells. Science, 239:914-916.

Knecht, M., Witt M, Abolmaali N, et al. (2003). The human vomeronasal organ. Nervenarzt. 74(10):858-862.

Konturek SJ, Pepera J, Zabielski K, et al. (2003): Brain-gut axis in pancreatic secretion and appetite control. J Physiol Pharmacol 54:3:293-317.

Koyanagi, M., Brandes, R.P., Haendeler, J., Zeiher, A.M. and Dimmeler, S. (2005) Cell-to-cell connection of endothelial progenitor cells with cardiac myocytes by nanotubes: a novel mechanism for cell fate changes? Circ Res 96: 1039-1041. 
Krantic, S., Goddard, I., Saveanu, A., et al., (2004). Novel modalities of somatostatin actions. Eur. J. Endocrinol. 151, 643-655.

Labrie, F., Belanger, A., Simard, J., Luu-The, V. \& Labrie, C. (1995). DHEA and peripheral androgen and estrogen formation: intracrinology, Ann. N.Y. Acad. Sci. 774 16-28.

Labrie, F., Luu-The, V., Labrie, C., Belanger, A., Simard, J., Lin, S.X. \& Pelletier, G. (2003). Endocrine and intracrine sources of androgens in women: inhibition of breast cancer and other roles of androgens and their precursor dehydroepiandrosterone, Endocr. Rev. 24:152-182.

Lee TH, Seng S, Sekine M. et al. (2007). Vascular endothelial growth factor mediates intracrine survival in human breast carcinoma cells through internally expressed VEGFR1/FLT1. PloS Med. 4(6):e186.

Li, W. \& Keller, G. (2000). VEGF nuclear accumulation correlates with phenotypical changes in endothelial cells. J Cell Sci 113: 1525-1534.

Martinez, V., Barrachina, M.D., Ohning, G. \& Taché, Y. (2002). Cephalic phase of acid secretion involves activation of medullary TRH receptor subtype 1 in rats. Am J Physiol Gastrointest Liver Physiol. 283(6):G1310- G1319.

Massagué, J. (1990). Transforming growth factor-a. A model for membrane-anchored growth factors. J. Biol. Chem. 265:21393-21396.

Matsuno M, Matsui T, Iwasaki A, Arakawa Y. (1997). Role of acetylcholine and gastrinreleasing peptide (GRP) in gastrin secretion. J Gastroenterol. 32(5):579-586.

Matzuk, M.M., Burns, K.H., Viveiros, M.M. and Eppig, J.J. (2002). Intercellular communication in the mammalian ovary: oocytes carry the conversation. Science. Vol. 296, 2178-2180.

Mayer, E.A. and Baldi, J.P. (1991). Can regulatory peptides be regarded as words of a biological language? Am J Physiol 261: G171-G184.

McLachlan, J.B., Hart, J.P., Pizzo, S.V. et al., (2003). Mast cell-derived tumor necrosis factor induces hypertrophy of draining lymph nodes during infection. Nat. Immunol. 4(12):1199-205.

Meşe, G., Richard, G. and White, T.W. (2006). Gap junctions: basic structure and function. Journal of Investigative Dermatology, Vol.127, 2516-2524.

Miller, M.B. and Bassler, B.L. (2001). Quorum sensing in bacteria. Annu Rev Microbiol. 55:16599.

Miller, L.J. (2003). Organization of the gut endocrine system. In: T. Yamada, D.H. Alpers, N. Kaplowitz, L Laine, C Owyang, D.W. Powell (Eds), Textbook of Gastroenterology, 4th ed, pp. 48-77, Lippincott Williams \& Wilkins, Philadelphia.

Musumeci, F., Scordino, A., Triglia, A., Blandino, G., Milazzo, I. (1999). Intercellular communication during yeast cell growth. Europhysics Letters 47: 736-742.

Nathan, C. and Sporn, M. (1991). Cytokines in context. J Cell Biol. 113:5: 981-986.

Niggli H. (1992). Ultraweak photons emitted by cells: biophotons. Journal of Photochemistry and Photobiology B 14: 144-146.

Öberg, K. (Ed), (1998). Neuroendocrine gut and pancreatic tumours; tumour biology, diagnosis and treatment. Novartis Pharma AG, Basel.

Patel, K.D., Lorant, E., Jones, D.A., et al. (1993). Juxtacrine interactions of endothelial cells with leukocytes: tethering and signaling molecules. Behring Inst. Mitt. 92, 144-64.

Pechère, J-C. (ed), (2007). The Intelligent Microbe. First ed. Frison-Roche. 
Perez, C., Albert, I., DeFay, K., Zachariades, N., Gooding, L., and Kriegler, M. (1990). A nonsecretable cell surface mutant of tumor necrosis factor (TNF) kills by cell-to-cell contact. Cell. 63, 251-258.

Peters J, Obermüller N, Woyth A, Peters B, Maser-Gluth C, Kranzlin B \& Gretz N. (1999). Losartan and angiotensin II inhibit aldosterone production in anephric rats via different actions on the intraadrenal renin-angiotensin system. Endocrinology 140: 675-682.

Prien, S., Lox, C., Messer, R. and DeLeon, F. (1990). Seminal concentrations of total and ionized calcium from men with normal and decreased motility. Fertil Steril 54:171172.

Raybould, H.E., Pandol, S.J., Yee, H., (2003). The integrated responses of the gastrointestinal tract and liver to a meal. In: T. Yamada, D.H. Alpers, N. Kaplowitz, L Laine, C Owyang, D.W. Powell (Eds), Textbook of Gastroenterology, 4th ed, pp. 2-12, Lippincott Williams \& Wilkins, Philadelphia.

Re, R. (1999). The nature of intracrine peptide hormone action. Hypertension 34: 534-538.

Re, R.N. (1989). The cellular biology of angiotensin: paracrine, autocrine and intracrine action in cardiovascular tissues. J Mol Cell Cardiol 21, Suppl 5: 63-69.

Re, R.N. (2003a). Intracellular rennin and the nature of intracrine enzymes. Hypertension, 42:117-122.

Re, R.N. (2003b). Implications of intracrine hormone action for physiology and medicine. Am J Physiol Heart Circ Physiol, 284: H751-H757.

Re, R.N. and Bryan, S.E. (1984). Functional intracellular renin-angiotensin systems may exist in multiple tissues. Clin Exp Hypertens A6, Suppl 10-11: 1739-1742.

Rojas, A., Figueroa, H. and Morales, E. (2010). Fueling inflammation at tumor microenvironment: the role of multiligand/rage axis. Carcinogenesis. Vol.31, No.3 pp. 334-341.

Ruan, W.J. and Lai, M.D. (2004). Autocrine stimulation in colorectal carcinoma (CRC). Medical Oncology, vol. 21, no. 1, 1-7.

Rustom, A., Saffrich, R., Markovic, I., Walther, P., Gerdes, H.H. (2004) Nanotubular highways for intercellular organelle transport. Science 303: 1007-1010.

Sasano, H., Suzuki, T., Miki, Y. \& Moriya, T. (2008). Intracrinology of estrogens and androgens in breast carcinoma. J Steroid Biochem \& Mol Biol. 108: 181-185.

Schechter, A.N. and Gladwin, M.T. (2003). Hemoglobin and the paracrine and endocrine functions of nitric oxide. N Engl J Med. 348:15:1483-1485.

Schusdziarra, V. (1993). Physiologic regulation of gastric acid secretion. Z Gastroenterol. 31(3):210-5.

Shannon, C.E. (1948). A mathematical theory of communication. Bell Syst Tech J 27:379-423.

Sliwa, L. (2003). Chemotaxis of spermatozoa--an important and little known process accompanying fertilization. Folia Med Cracov. 44(1-2):153-8.

Spehr, M., Schwane, K., Riffell, J.A. et al. (2004). Particulate adenylate cyclase plays a key role in human sperm olfactory receptor-mediated chemotaxis. J. Biol. Chem. 279(38):40194-40203.

Sporn, M.B., Roberts, A.B. (1988). Peptide growth factors are multifunctional. Nature 332, 217-219.

Sporn, M.B., Roberts, A.B. (1992). Autocrine secretion-10 years later. Ann Int Med. 117:408414. 
Sporn, M.B., Todaro, G.J. (1980). Autocrine secretion and malignant transformation of cells. New Engl. J. Med. 303, 878-880.

Sternberg, E.M. (1997). Emotions and disease: From balance of humors to balance of molecules. Nat. Med. 3, 264-7.

Trosko, J.E. (2007). Gap junctional intercellular communication as a biological "Rosetta Stone" in understanding, in a systems biological manner, stem cell behavior, mechanisms of Epigenetic Toxicology, chemoprevention and chemotherapy. J Membrane Biol. 218: 93-100.

Valiunas, V., Polosina, Y.Y., Miller, H. et al. (2005). Connexin-specific cell-to-cell transfer of short interfering RNA by gap junctions. J Physiol. 568:459-468.

Vincent, L.M. (1994). Reflexions on the usage of information theory in biology. Acta Biotheor. 42(2-3): 167-179.

Vinken, M., Vanhaecke, T., Papeleu, P., Snykers, S., Henkens, T. and Rogiers V. (2006) Connexins and their channels in cell growth and cell death. Cell Signal 18:592-600.

Waldum, H.L., Kleveland, P.M., Sandvik, A.K., Brenna, E., Syversen, U., Bakke, I. and Tommeras, K. (2002). The cellular localization of the cholecystokinin 2 (gastrin) receptor in the stomach. Pharmacol Toxicol. 91(6):359-62.

Weihe, E., Nohr, D., Michel, S., Muller, S., Zentel, H.J., Fink, T. \& Krekel, J. (1991). Molecular anatomy of the neuro-immune connection. Int. J. Neurosci. 59, 1-23.

White, T.W., Paul, D.L. (1999) Genetic diseases and gene knockouts reveal diverse connexin functions. Annu Rev Physiol 61:283-310.

Zimmerman, G.A., Lorant, D.E., McIntyre, T.M. \& Prescott, S.M. (1993). Juxtacrine intercellular signaling: another way to do it. Am. J. Respir. Cell Mol. Biol. 9, 573577. 


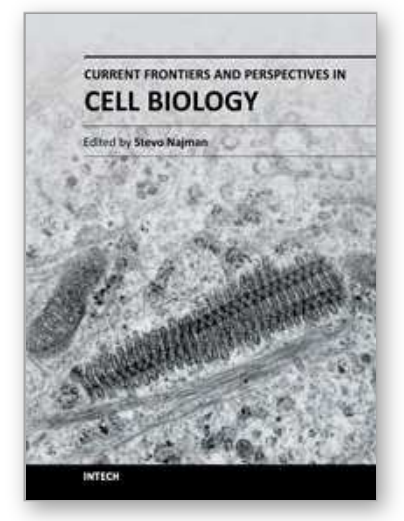

\section{Current Frontiers and Perspectives in Cell Biology \\ Edited by Prof. Stevo Najman}

ISBN 978-953-51-0544-2

Hard cover, 556 pages

Publisher InTech

Published online 25, April, 2012

Published in print edition April, 2012

\section{How to reference}

In order to correctly reference this scholarly work, feel free to copy and paste the following:

Nuri Faruk Aykan (2012). Intercellular Communication, Current Frontiers and Perspectives in Cell Biology, Prof. Stevo Najman (Ed.), ISBN: 978-953-51-0544-2, InTech, Available from:

http://www.intechopen.com/books/current-frontiers-and-perspectives-in-cell-biology/intercellularcommunication

\section{INTECH}

open science | open minds

\section{InTech Europe}

University Campus STeP Ri

Slavka Krautzeka 83/A

51000 Rijeka, Croatia

Phone: +385 (51) 770447

Fax: +385 (51) 686166

www.intechopen.com

\section{InTech China}

Unit 405, Office Block, Hotel Equatorial Shanghai

No.65, Yan An Road (West), Shanghai, 200040, China

中国上海市延安西路65号上海国际贵都大饭店办公楼405单元

Phone: +86-21-62489820

Fax: +86-21-62489821 
(C) 2012 The Author(s). Licensee IntechOpen. This is an open access article distributed under the terms of the Creative Commons Attribution 3.0 License, which permits unrestricted use, distribution, and reproduction in any medium, provided the original work is properly cited. 